Marquette University

e-Publications@Marquette

College of Education Faculty Research and

Publications

Education, College of

4-1-1995

Prospective Minority Students' Perceptions of Application Packets for Professional Psychology Programs: A Qualitative Study

Joseph Ponterotto

Fordham University

Alan W. Burkard

Marquette University, alan.burkard@marquette.edu

Roland Yoshida

Queens College

Anthony A. Cancelli

Fordham University

Giovanni Mendez

Fordham University

See next page for additional authors

Accepted version. Professional Psychology: Research and Practice, Vol. 26, No. 2 (April 1995): DOI. (C) 1995 American Psychological Association. Used with permission.

This article may not exactly replicate the final version published in the APA journal. It is not the copy of record.

Alan Burkard was affiliated with Fordham University at the time of publication. 


\section{Authors}

Joseph Ponterotto, Alan W. Burkard, Roland Yoshida, Anthony A. Cancelli, Giovanni Mendez, Lynn Wasilewski, and Lynn Sussman 


\title{
Prospective Minority Students' Perceptions of Application Packets for Professional Psychology Programs: A Qualitative Study
}

\author{
Joseph G. Ponterotto \\ Fordham University-Lincoln Center \\ Manhattan, NY \\ Alan Burkard \\ Fordham University-Lincoln Center \\ Manhattan, NY \\ Roland K. Yoshida \\ Queens College, City University of New York \\ Queens, NY \\ Anthony A. Cancelli \\ Fordham University-Lincoln Center \\ Manhattan, NY \\ Giovanni Mendez \\ Fordham University-Lincoln Center \\ Manhattan, NY \\ Lynn Wasilewski \\ Fordham University-Lincoln Center \\ Manhattan, NY \\ Lynn Sussman \\ Fordham University-Lincoln Center \\ Manhattan, NY
}

Professional Psychology: Research and Practice, Vol. 26, No. 2 (April 1995): pg. 196-204. DOI. This article is @ American Psychological Association and permission has been granted for this version to appear in e-Publications@Marquette. American Psychological Association does not grant permission for this article to be further copied/distributed or hosted elsewhere without the express permission from American Psychological Association. 
NOT THE PUBLISHED VERSION; this is the author's final, peer-reviewed manuscript. The published version may be accessed by following the link in the citation at the bottom of the page.

\begin{abstract}
This article reports the results of a qualitative study designed to determine issues salient in Black and Hispanic American students' review and evaluation of program-application packets in professional psychology. The study served as an extension to the Yoshida et al. (1989) quantitative investigation. Students interested in pursuing doctoral studies in counseling or school psychology $(\mathrm{N}=22)$ served as the sample. The qualitative methodology incorporated a think-aloud procedure and semistructured interviews. A theme analysis of transcribed interviews identified both major and minor themes central to participants' evaluation of the packets. Major themes included financial aid, program requirements and course descriptions, demography of the student body, and the quality and clarity of application material. Specific suggestions on developing an application packet to send to inquiring prospective students are put forth. It is recommended that such a packet could serve as a cost-effective minority-recruitment strategy.
\end{abstract}

In recent years, professional psychology programs have begun to devote greater emphasis to multicultural training issues. This emphasis has been reflected in increased attention to multicultural curriculum (see recent surveys by Hills \& Strozier, 1992; Rogers, Ponterotto, Conoley, \& Wiese, 1992) and in intensified efforts to attract more minority students and faculty to graduate psychology programs (Hammond \& Yung, 1993). Evidence suggests, however, that on the national level, psychology programs have met with only minimal success in attracting racial-ethnic minority students and scholars. Ponterotto and Casas (1991) reported that although roughly $25 \%$ of the U.S. population is composed of racial-ethnic minority individuals (namely, African Americans, Hispanic Americans, AsianAmerican/Pacific Islanders, and American Indians), only $11 \%$ of fulltime doctoral students in psychology and $5 \%$ of full-time faculty represent racial-ethnic minority groups (see also Hammond \& Yung, 1993).

Current demographic projections indicate that within three or four decades minority persons as a collective group will constitute the country's numerical majority (over $50 \%$ of the population; Ponterotto \& Casas, 1991; Sue \& Sue, 1990). It is clear that in coming years professional psychologists will come into increasing contact with a culturally diverse clientele. Given these demographic trends, psychology training programs will be confronted with increasing pressure and desire to attract more minority students.

A first step in attracting more minority students to one's program involves assessing current recruitment practices. Bernal,

Professional Psychology: Research and Practice, Vol. 26, No. 2 (April 1995): pg. 196-204. DOI. This article is @ American Psychological Association and permission has been granted for this version to appear in e-Publications@Marquette. American Psychological Association does not grant permission for this article to be further copied/distributed or hosted elsewhere without the express permission from American Psychological Association. 
Barron, and Leary (1983) examined the ethnic minority information contained in application packets mailed to a fictitious prospective applicant to clinical psychology doctoral programs. These authors found that a modest relationship existed between minority information included in application packets and the proportions of minority students enrolled in the programs. Bernal et al. (1983) concluded their article by stressing that psychology programs attend more seriously to the preparation of their program description and application materials. They noted that the modification of application materials would be a "low-cost/high-potential strategy" (p. 828) for programs engaged in serious affirmative action efforts.

In a replication and extension of the Bernal et al. (1983) methodology, Yoshida, Cancelli, Sowinski, and Bernhardt (1989) mailed a letter requesting program information to doctoral programs in clinical, counseling, and school psychology. This letter indicated the name of the prospective (but fictitious) applicant, "Chris Boyer/Maldonado," and in three different versions mentioned that Chris was either Black, Hispanic, or did not mention race-ethnicity (a "no-race" condition). Yoshida et al. (1989) found that minority condition "Chris Boyer/Maldonado" was, in general, more likely to receive a response than a no-race condition and that the minority conditions received more personal forms of communication than the no-race condition.

Yoshida et al. (1989) also had six undergraduate senior psychology majors "who were interested in pursuing a doctoral degree in professional psychology" (p. 181) rate on a Likert-type scale the various application materials on a number of criteria, including "to what degree did the materials encourage Chris to apply to this psychology program?" (p. 181). The overall finding of this aspect of the study was that programs were only marginally responsive to Chris's specific questions and that "few programs are using materials sent to prospective minority applicants as a method for implementing their affirmative action policy" (p. 184). The authors suggested that programs may not be using application materials as a minority recruitment device because they may not be aware of what information is important. 
NOT THE PUBLISHED VERSION; this is the author's final, peer-reviewed manuscript. The published version may be accessed by following the link in the citation at the bottom of the page.

More recently, Hammond and Yung (1993) surveyed recruitment and retention strategies used by 35 member schools of the National Council of Schools of Professional Psychology. The survey used a checklist format and was completed by "key administrators" at the 35 schools. The recruitment strategy option that most closely matched the focus of the present study (as well as the previous Bernal et al., 1983, and Yoshida et al., 1989, studies) read "recruitment materials especially developed for minority students" (p. 8). The survey found that $43 \%$ of the responding programs incorporated this recruitment strategy. In reviewing the results of their comprehensive survey, Hammond and Yung (1993) noted that "many of the professional schools are using a variety of strategies to promote greater minority participation in their training programs. However, their limited success in terms of ethnic minority student enrollment indicates that much more vigorous and diverse strategies are needed" (p. 10).

Collectively, the Bernal et al. (1983), Yoshida et al. (1989), and Hammond and Yung (1993) studies provide valuable information for professional psychology programs seeking to attract more minority applicants. One limitation of these studies, however, is their reliance on administrators for program information. For example, in the Hammond and Yung (1993) checklist survey, what guarantee is there that the administrators provided accurate and reliable information? Although it can be assumed that the checklists were completed in good faith, surveys on "politically correct" topics are not without limitation (Ponterotto \& Casas, 1991).

What would be helpful to professional psychology programs at this point is descriptive information on what prospective minority students look for when choosing to apply to (or enter) a doctoral program. Furthermore, given inherent limitations of survey research (see Stage \& Russell, 1992) and the fact that survey methods have dominated multicultural research (cf. Ponterotto \& Casas, 1991), it would behoove the profession to incorporate more qualitative research in this topical area.

The purpose of the present study was to extend previous survey research, particularly the Yoshida et al. (1989) investigation, by examining intensively how prospective minority applicants process

Professional Psychology: Research and Practice, Vol. 26, No. 2 (April 1995): pg. 196-204. DOI. This article is (C American Psychological Association and permission has been granted for this version to appear in e-Publications@Marquette. American Psychological Association does not grant permission for this article to be further copied/distributed or hosted elsewhere without the express permission from American Psychological Association. 
application material and come to a decision about whether to apply to a given school. The major goal of this study was to create a descriptive database that would yield specific suggestions on what to include in application materials and how to package such material sent to prospective applicants.

\section{Method}

\section{Qualitative Research}

Recent writers in the area of minority issues in psychology have emphasized the need to augment traditional quantitative methodology with qualitative methods (see Helms, 1989; Ponterotto \& Casas, 1991; Schofield \& Anderson, 1987). Qualitative methods are not designed to test theoretically postulated hypotheses, rather their purpose is to uncover important variables around the question of inquiry (Marshall \& Rossman, 1989). The present study incorporated qualitative methods to identify those variables most salient to minority students who are considering applying to doctoral programs in counseling and school psychology.

Two qualitative methodologies were incorporated in the present study: the think-aloud procedure (Aanstoos, 1983; Meyers \& Lytle, 1986) and semi-structured interviews (Kerwin, Ponterotto, Jackson, \& Harris, 1993; McCracken, 1988; Ponterotto \& Casas, 1991; Taylor \& Bogdan, 1984).

\section{Think-aloud procedure}

The think-aloud procedure, conceptually linked to research in cognitive psychology (e.g., Weinstein \& Mayer, 1986), has served as an important research tool in the areas of learning, comprehension, and problem solving. Initial use of this procedure focused on assessing reading comprehension by asking students to think aloud while reading a passage. This procedure has since been found to be useful in a number of areas and has been used effectively both as a tool for research and for clinical practice (e.g., as part of an assessment battery; Meyers \& Lytle, 1986).

Professional Psychology: Research and Practice, Vol. 26, No. 2 (April 1995): pg. 196-204. DOI. This article is @ American Psychological Association and permission has been granted for this version to appear in e-Publications@Marquette. American Psychological Association does not grant permission for this article to be further copied/distributed or hosted elsewhere without the express permission from American Psychological Association. 
An important advantage of the think-aloud procedure is that it allows the researcher to observe, in the moment, how a participant processes, comprehends, prioritizes, and comes to a decision about a given set of information. Consistent with the qualitative tradition (Taylor \& Bogdan, 1984), the think-aloud procedure is unobtrusive, allowing participants free expression with minimal prompting from the researcher. The specific use of this procedure in the present study will be elaborated on in the Procedure section.

\section{Semistructured interview}

McCracken (1988) described the long-interview method (or semistructured interview) as "one of the most powerful methods in the qualitative armory ... [it] gives us the opportunity to step into the mind of another person, to see and experience the world as they do themselves" (p. 9). In selecting the long or semistructured interview over the traditional unstructured interview, we followed the guidelines and recommendations of Ponterotto and Casas (1991). These authors noted that semistructured interviews "are intended to be fairly indepth, yet shorter and more structured than the fully unstructured interview. Semi-structured interviews are ideal when the researcher is interested in a broad range of persons, situations, or settings. A semistructured interviewer also has a clearer sense of the specific subtopics to be covered in the interview" (Ponterotto \& Casas, 1991, p. 127). The subsequent Procedure section clarifies the use of the semistructured interview in the present study.

\section{Sample}

The target sample included African-American and HispanicAmerican adults who were enrolled in or recently had graduated from master's degree programs in counseling, counseling psychology, or school psychology. The participants were familiar with the substance of their specialty and could be considered to be in a pool of prospective candidates for doctoral programs.

Our sampling procedure followed recommended guidelines for qualitative interviews (Kerwin et al., 1993; McCracken, 1988; Ponterotto \& Casas, 1991; Taylor \& Bogdan, 1984). McCracken (1988) emphasized that the selection of interviewees should not follow

Professional Psychology: Research and Practice, Vol. 26, No. 2 (April 1995): pg. 196-204. DOI. This article is (C American Psychological Association and permission has been granted for this version to appear in e-Publications@Marquette. American Psychological Association does not grant permission for this article to be further copied/distributed or hosted elsewhere without the express permission from American Psychological Association. 
quantitative sampling rules, as these participants do not constitute a sample in the quantitative sense. He recommended that potential interviewees generally be strangers, be few in number, and not possess special knowledge or ignorance of the topic under inquiry. Furthermore, McCracken recommended that there be some contrast within the sample in terms of one or more of the following characteristics: age, gender, status, occupation, and education.

Consistent with qualitative interviewing (semistructured format), the present study incorporated the sampling procedure known as theoretical sampling. In theoretical sampling, no preselected number of participants is determined, and interviewing continues as long as each case adds meaningful data to the general research questions under study. When additional cases cease to add meaningful data, the theoretical saturation point is reached, and data collection terminates (see Ponterotto \& Casas, 1991; Taylor \& Bogdan, 1984).

We recruited our sample from three institutions in the New York metropolitan area. Participants for the study were recruited through word-of-mouth contact with colleagues, students, and the initial participants. Additionally, flyers announcing the study and inviting participation were posted in the psychology department areas of the three institutions. Our theoretical saturation point was reached at 22 participants.

The sample included 13 African Americans, 8 Hispanic Americans, and 1 biracial individual. Seven of the participants were from school psychology and 15 from counseling or counseling psychology. One half of the sample was monolingual, and the other half was either bilingual or trilingual. Consistent with the composition of the training programs in the local area, the majority of participants were female $(n=19)$. Both the mean and median age for the sample was 34 years.

\section{Procedure}

Each participant was interviewed for 1.5 to $2 \mathrm{hr}$. The interview consisted of two parts: first the think-aloud procedure and then the semistructured interview. 
NOT THE PUBLISHED VERSION; this is the author's final, peer-reviewed manuscript. The published version may be accessed by following the link in the citation at the bottom of the page.

\section{Stimulus material}

As stimuli for the think-aloud procedure, participants were presented with two application packets for professional psychology programs, in a random order. These packets were taken from the Yoshida et al. (1989) study in which the application packets from five (out of 98) counseling psychology and three school psychology programs were rated as highly encouraging. We decided to select from among packets rated "highly encouraging" because these packets offered increased opportunity for qualitative discussion. Two packets each from the counseling psychology and school psychology programs were selected from these eight. An attempt was made to select packets with different types of information and formats so as to elicit varied responses from subjects. Table 1 presents the characteristics of the four program packets selected as stimuli for the think-aloud procedure and the semistructured interviews.

\section{Think-aloud procedure}

Each participant was presented with the fictitious "Chris Boyer/Maldonado" letter that was used to request application packets in the Yoshida et al. (1989) study. This letter read as follows:

I will be graduating from Brooklyn College this June with a B.S. in Psychology. I am interested in continuing my studies in psychology on the graduate level. Specifically, I would like to earn my doctorate in School Psychology [or Counseling Psychology]. Being Black [or Hispanic, or no mention of raceethnicity], I am particularly interested in a program that will prepare me to work as a professional psychologist in my community. I am looking forward to returning to Brooklyn to work after completing my degree.

Although I am young with no experience as a psychologist, I have worked as a volunteer in my community with adolescents. This experience has shown me the need for well-trained psychologists. I am looking for a program that will provide me the opportunity to gain the necessary skills to become a good psychologist. However, in helping me decide which program meets my needs I would like information concerning types of financial aid which are available to me.

Professional Psychology: Research and Practice, Vol. 26, No. 2 (April 1995): pg. 196-204. DOI. This article is @ American Psychological Association and permission has been granted for this version to appear in e-Publications@Marquette. American Psychological Association does not grant permission for this article to be further copied/distributed or hosted elsewhere without the express permission from American Psychological Association. 
NOT THE PUBLISHED VERSION; this is the author's final, peer-reviewed manuscript. The published version may be accessed by following the link in the citation at the bottom of the page.

I hope you will find time to send me the information I need. I am looking forward to applying to your program.

Both the counseling and school psychology participants were given their respective packets in random order. Each student was read the same instructions about how they were to review the packets and how they were to think aloud during the review process. These instructions were as follows:

This study is a follow-up to an investigation of how professional psychology programs respond to requests from minority group members. Because you are a minority group member, we are interested in finding out if the material you review helps you decide whether you will apply to the school presented.

Here is what I would like you to do: Assume that you are interested in and wish to apply to a graduate degree program in psychology (regardless of type of program or the geographic location of the university). This is the letter you mailed to the various programs to request the information packets [participant is shown and then reads the stimulus letter (see above)]. You have just received the packets and are about to look through them. As you do, I would like for you to think out loud whatever makes an impression or is of interest to you, even if you consider it trivial. Remember, it could be anything you see or read. Do you understand?

If both packets contain similar materials that are of interest to you, it is perfectly fine to say so. However, it is important that you do not make comparisons between packets, but go through each packet individually. You will have 20 minutes to review each packet. I will let you know when there are 10 and then 5 minutes left to review. Please treat the review process seriously. We will ask whether you would apply to any of the reviewed universities and what materials were helpful in making your decision. Do you have any questions?

To facilitate the think-aloud process, participants were given the verbal prompt "tell me what you're thinking" after every 30 -second period of silence. During the process, the examiner took detailed notes on prepared coding sheets ${ }^{1}$. The coding forms were divided into sections by type of program material (i.e., cover letter, application forms, program brochure, university catalogue, other). As the participant thought aloud about particular components of the material,

Professional Psychology: Research and Practice, Vol. 26, No. 2 (April 1995): pg. 196-204. DOI. This article is (C American Psychological Association and permission has been granted for this version to appear in e-Publications@Marquette. American Psychological Association does not grant permission for this article to be further copied/distributed or hosted elsewhere without the express permission from American Psychological Association. 
the researcher would write down these thoughts in the appropriate section. The think-aloud procedure was audio-recorded, ranged in length from $45 \mathrm{~min}$ to $1 \mathrm{hr}$, and averaged $50 \mathrm{~min}$.

\section{Semistructured interviews}

Immediately following the think-aloud procedure, each participant underwent a semistructured interview. The interviews were unstructured to the degree that the interview dyad became comfortable with one another, and the interviewee was encouraged to share any thoughts, feelings, perceptions or opinions about the packets being reviewed specifically or the doctoral application process generally. The goal was to engage in in-depth qualitative interviewing in which the interviewee's perceptions were of paramount importance and in which the interviewer became part of the research process (Kerwin et al., 1993; Ponterotto \& Casas, 1991; Taylor \& Bogdan, 1984).

The semistructured nature of the interview involved the use of a general guide to remind the examiner to query specific areas if the subject failed to address them spontaneously. The contents of the interview guide were generated from a review of the relevant literature (particularly Bernal et al., 1983, and Yoshida et al., 1989) and from discussion among the seven coauthors. Areas specified in the interview guide included to which of the two programs the applicant might apply and why; specific comments on the cover letter and its personal (personally addressed and hand signed) or impersonal nature; perspectives on the packets' inclusion of financial aid information; demographic characteristics of the student and faculty bodies in the program and in the university as a whole; faculty backgrounds and research interests; participants' perceptions of the stated admissions requirements (Graduate Record Examination $\AA^{2}$ [GRE $\left.\AA_{1}, 1994\right]$ scores, grades); application deadlines; cross-cultural inclusion in curriculum; and minority field experiences, among others. The semistructured interviews were audio-recorded and ranged in length from $45 \mathrm{~min}$ to 1 hr.

Professional Psychology: Research and Practice, Vol. 26, No. 2 (April 1995): pg. 196-204. DOI. This article is @ American Psychological Association and permission has been granted for this version to appear in e-Publications@Marquette. American Psychological Association does not grant permission for this article to be further copied/distributed or hosted elsewhere without the express permission from American Psychological Association. 
NOT THE PUBLISHED VERSION; this is the author's final, peer-reviewed manuscript. The published version may be accessed by following the link in the citation at the bottom of the page.

\section{Validity Assessment}

A method of validity in qualitative methodology is known as triangulation. Triangulation refers to "the combination of methods or sources of data in a single study" that are used to verify the consistency of responses to the research questions (Taylor \& Bogdan, 1984 , p. 68). Pon terotto and Casas (1991) discuss three forms of triangulation: source triangulation, in which the researcher seeks similar topical information from a variety of sources; investigator triangulation, in which multiple researchers or interviewers are engaged in the fieldwork; and method triangulation, in which multiple yet conceptually related methodologies are used with each research participant.

In the present study, all three methods of triangulation were incorporated. Source triangulation was used by sampling participants from three different higher education institutions. Investigator triangulation was evident with the use of multiple interviewers. A key component of qualitative methodology is to allow the research method and questions to evolve as the study progresses. In this case the interview team met biweekly to discuss their perceptions and to consider whether additional questions were being raised that other team members should look into in their next interviews. Finally, method triangulation was incorporated by subjecting each research participant to two conceptually related methods-the think-aloud procedure and the semistructured interview. Although it would be expected that similar information, perceptions, and so forth would arise from both methods, it is also possible that additional information could be generated from the incorporation of a second qualitative methodology.

We conducted a pilot study with 5 undergraduate psychology students recruited from one of the researchers' home institutions. The pilot study allowed the research team to test and practice the methodology and the theme analysis procedures. As a result of the pilot investigation, some minor changes were made in think-aloud instructions and in the semistructured interview guide. These modifications were reflected throughout the Procedure section.

Professional Psychology: Research and Practice, Vol. 26, No. 2 (April 1995): pg. 196-204. DOI. This article is @ American Psychological Association and permission has been granted for this version to appear in e-Publications@Marquette. American Psychological Association does not grant permission for this article to be further copied/distributed or hosted elsewhere without the express permission from American Psychological Association. 
NOT THE PUBLISHED VERSION; this is the author's final, peer-reviewed manuscript. The published version may be accessed by following the link in the citation at the bottom of the page.

\section{Ethical Considerations}

Treatment of participants followed the Ethical Principles of the American Psychological Association (APA, 1990). Students understood that that their participation was voluntary and that their consent to participate could be withdrawn at any time during the study. No participant deception was necessary in the conduct of the study. Furthermore, the four universities whose packets were used as stimuli provided written consent allowing their material to be incorporated into the study.

Some writers in the field (i.e., Casas \& Thompson, 1991; Ponterotto \& Casas, 1991) have emphasized that from an ethical perspective, research should do more than refrain "from harming" participants but in fact should provide tangible benefits to the participants in the study. Accordingly, our participants were fully prebriefed and debriefed before and after the study. Any questions about doctoral training and the admissions process presented by the participants were answered completely. Finally, each participant was paid $\$ 15$ for his or her participation in the study. Debriefing of participants indicated that they believed being in the study expanded their knowledge base with regard to the doctoral application process.

\section{Results}

A review of audiotapes, process notes, and interview transcripts yielded both major and minor themes relevant to the participants' review and decision process. Data-sorting and reduction procedures specified in Kerwin et al. (1993) were used in the present study. In the theme analysis, major and minor themes were distinguished by the frequency and emphasis of participants' reports. Major themes were noted by all or the majority of participants and were mentioned with emphasis. Minor themes represent topics covered by at least $50 \%$ of the participants, and the themes are emphasized somewhat less than major theme topics.

Themes arose in the think-aloud procedure and were further probed and reinforced during the semistructured interview. No themes arose uniquely from the semistructured interviews. On the basis of our

Professional Psychology: Research and Practice, Vol. 26, No. 2 (April 1995): pg. 196-204. DOI. This article is @ American Psychological Association and permission has been granted for this version to appear in e-Publications@Marquette. American Psychological Association does not grant permission for this article to be further copied/distributed or hosted elsewhere without the express permission from American Psychological Association. 
theme criteria, we identified four major themes and a number of minor themes. The major themes included financial aid, program requirements, student demographics, and quality of the application materials. Minor themes focused in the areas of admissions and application procedures, admission criteria, faculty demographics, faculty research on diversity issues, community information, career information, and personal contact sources.

\section{Major Themes}

\section{Financial aid information}

Participants consistently sought financial aid information on opening the program packets. Participants' feelings about financial aid tended to be one of the first issues raised in the review of packets and elicited strong emotions about their potential application to a program. One participant stated, "I think in any package I got [ financial aid] would probably be my first consideration." Another participant noted, "the first thing that comes out is that they [the program] are mentioning that at some point financial aid is available. That is an important issue."

Interest was expressed about assistantships, scholarships, fellowships, and special awards available for minority students. For example, one participant stated, "the opportunity for minority fellowships would certainly encourage me to apply." It is interesting that the availability of financial aid specifically targeted for minority students surprised some participants.

Overall, participants expressed dismay about the comprehensiveness of the financial aid information. This information seemed to leave most participants confused about the availability of financial aid. For example, some participants were interested to know their actual chances of receiving the aid advertised. One participant stated that "I would be interested in scholarship information and then ascertain whether I met the criteria that they desire." A number of participants indicated an unwillingness to apply to programs not offering financial aid.

Professional Psychology: Research and Practice, Vol. 26, No. 2 (April 1995): pg. 196-204. DOI. This article is @ American Psychological Association and permission has been granted for this version to appear in e-Publications@Marquette. American Psychological Association does not grant permission for this article to be further copied/distributed or hosted elsewhere without the express permission from American Psychological Association. 
NOT THE PUBLISHED VERSION; this is the author's final, peer-reviewed manuscript. The published version may be accessed by following the link in the citation at the bottom of the page.

\section{Program requirements and course descriptions}

Participants were very interested to know the program's requirements and graduation timeline. Respondents looked for specific course descriptions. One student noted, "I think it would be helpful to see a schedule of course offerings ... to see what courses are required." Consistently, multicultural coursework was identified by participants as an area of personal interest and as a topic necessary to the program in general.

Participants indicated that they were looking for a mixture of applied and theoretical multicultural coursework. For example, a course listing titled Theory of Black Personality Development intrigued many participants. Other participants indicated looking for courses in establishing therapeutic working alliances with other minority populations (i.e., Asian-American, gay-lesbian, Hispanic, or bilingual clients) and practicum or field work experiences with diverse racialethnic populations. One participant asked, "what and how are they approaching cross-cultural issues? Sometimes people see it just as Black and White, are there any other cultures?" Participants tended to emphasize practical applications in counseling rather than research applications.

\section{Demography of student body}

All participants expressed a high level of curiosity about student demographics. They were interested in the size of the program (total number of students and number of students in each year of doctoral study); the age, race, and gender breakdown; common past experiences of students (e.g., employment, schooling); and other characteristics.

With regard to the multicultural composition of the student body, some participants indicated that this was an important consideration in their decision to (or not to) apply to the given program, whereas other participants indicated this was not a concern. Roughly $50 \%$ of the participants noted that a lack of adequate racial minority representation in the program would deter them from applying to the school. When participants were asked to clarify adequate minority representation, they usually indicated that they did

Professional Psychology: Research and Practice, Vol. 26, No. 2 (April 1995): pg. 196-204. DOI. This article is (C American Psychological Association and permission has been granted for this version to appear in e-Publications@Marquette. American Psychological Association does not grant permission for this article to be further copied/distributed or hosted elsewhere without the express permission from American Psychological Association. 
not have a number in mind but rather that there was a general impression of other racial-ethnic minority students in the program. A number of respondents noted that they did not want to be the only member of their racial-ethnic group in the program. One participant indicated that "I think I am more comfortable when I see students with my background ... that there is a multicultural student body as well as faculty." Another participant stated, "it would be nice if they had applicants that were going to concentrate on minority mental health and they pictured a Black man and a Black woman sitting in class." Finally, a third participant, while reading the cover letter paused and noted, "although I'm reading the letter now, I probably would have looked at the catalogue first ... to see if there were any people of color-Black, or even Hispanic, or anything other than White, in the pictures."

Some participants also expressed skepticism concerning the program's stated commitment to increasing student diversity within the program. A few participants pleasantly noted the number of racialethnic minority graduates from one program.

It is important to note that about one half of the respondents did not consider the racial composition of the student body a critical factor in their decision to apply to the program. There was clearly diversity in students' opinions about this point. Nonetheless, all respondents were eager to gather a profile of the student body.

\section{Quality, clarity, and comprehensiveness of application material}

The final major theme drawn from our sample revolved around the quality, extent, and organization of the information presented. Participants expected the information to be concise, have an organizational flow, and have a sense of quality about the printing. Respondents often found, however, that the materials were difficult to read due to copies that were poorly reproduced (i.e., quality of print, alignment of printing on the page). Many participants commented that the obvious lack of attention to the quality of the printed materials demonstrated a lack of professionalism and a lack of concern for potential candidates. This elicited strong feelings in many participants, and in fact 1 participant stated, "you're [the program] sending this out to someone who is a potential student, and so not be concerned with

Professional Psychology: Research and Practice, Vol. 26, No. 2 (April 1995): pg. 196-204. DOI. This article is @ American Psychological Association and permission has been granted for this version to appear in e-Publications@Marquette. American Psychological Association does not grant permission for this article to be further copied/distributed or hosted elsewhere without the express permission from American Psychological Association. 
the print, its almost like you are not even concerned with this person, or that they might want to be at your school ... the fact that it's not clear is almost like they just don't give a damn. That is what this says to me."

Participants appreciated application packets that were visually attractive. One participant, while reviewing a packet, commented on the catalogue: "It's appealing because it is colorful, it's a piece of artwork that they show here." Responding to another packet, a different participant noted, "But right off, first impression, the catalogue doesn't look appealing to me ... Because it's [the school] away from home and I would have to go, I would really have to see more of the grounds, more of the buildings and more of the student population even if it was outdated; I would still like to see more pictures of the place itself."

Participants were looking for relevant and important information; their goal was to get a sense of the school and whether they might be admitted. Participants became frustrated if an application packet had either too little or too much information. While reviewing one application packet that did not include a full university catalogue, a participant stated, "they should have sent me a catalogue ... they should have sent more information." This same participant, while reviewing the second and more inclusive packet, stated, "they sent too much information, that's overwhelming."

Finally, the organizational layout of the application and informational materials often confused respondents. For example, participants struggled with matching course numbers to appropriate course descriptions and matching the right forms and paperwork with the requirements outlined in admission procedures.

\section{Minor Themes}

\section{Admission and application procedures}

Participants sought information on the admission and application procedures for programs. Often programs would clearly state a deadline for applications, but the procedures for completing the

Professional Psychology: Research and Practice, Vol. 26, No. 2 (April 1995): pg. 196-204. DOI. This article is @ American Psychological Association and permission has been granted for this version to appear in e-Publications@Marquette. American Psychological Association does not grant permission for this article to be further copied/distributed or hosted elsewhere without the express permission from American Psychological Association. 
application were less clear. Participants considered a clear description on the process of admission review with a tentative time line important.

A collateral issue is the significance of admission criteria, particularly the importance of GRE scores. Understanding the weighing of diverse selection criteria was deemed important, and several participants indicated this information served as a criteria for selecting to apply to a program. Participants indicated that they were not looking for special treatment but that they were concerned about the apparent overemphasis of the GRE scores as a selection criteria. Participants often suggested that the historically poor performance of minorities on the GRE could serve as a bias in the evaluation of their graduate application.

\section{Faculty demographics}

Minority representation among the faculty members seemed to be a significant factor for many participants. There was a perception that institutions with culturally diverse faculty were committed to the education of minority populations.

\section{Faculty research on diversity issues}

A number of participants expressed a desire that faculty members have research interests in diversity issues and be willing to mentor students on multicultural research projects. Participants also expected multicultural issues to be reflected in courses offered by the faculty.

\section{Community information}

A number of respondents expressed disappointment that more information on "living in the community" was not presented. Participants were looking for information on the demographics of the surrounding campus community, on the denomination of and distance to churches, on sample cultural events, and so forth. The availability and cost of housing in the local community was also discussed by 
some students who believed not enough of such information was included in the packet.

A number of participants were interested to know what efforts were made by the program and the university to help the graduate secure employment. The employment patterns of recent and past graduates were of interest to the participants; however, participants seemed uninterested in the type of positions obtained. By and large, the participants thought such information was lacking in the packets.

\section{Personal contacts}

Finally, participants believed that a personalized cover letter and a specified program contact person would be most helpful in pursuing program information and submitting the final application. Participants noted that this type of personal contact served as a welcome invitation to pursue the school's program and that it served as an "anchor" of information to the school.

\section{Discussion}

This qualitative study was designed to identify issues salient in minority students' review and evaluation of doctoral application packets. The study's need was grounded in the psychology's profession's strong call to address minority student underrepresentation in professional psychology (see Hammond \& Yung, 1993; Sue et al., 1992). The methodology chosen to address this need was qualitative in nature, in stark contrast to the preponderance of quantitatively based surveys that dominate the minority-student literature (see review in Ponterotto \& Casas, 1991).

The results of our study reveal both major and minor themes that professional psychology programs may wish to consider as they prepare application packets as a cost-effective device for minority student recruitment. In this Discussion section, we integrate the identified themes into a "model" application packet.

Professional Psychology: Research and Practice, Vol. 26, No. 2 (April 1995): pg. 196-204. DOI. This article is @ American Psychological Association and permission has been granted for this version to appear in e-Publications@Marquette. American Psychological Association does not grant permission for this article to be further copied/distributed or hosted elsewhere without the express permission from American Psychological Association. 


\section{Recommended Contents of Program or University Application Packets}

Below we present 10 recommendations with regard to the preparation of program application packets sent to inquiring prospective students.

1. The application packet should be well organized. It should include a university catalogue, a department or school catalogue, and a program-specific bulletin. Although including all three catalogues/bulletins in the packet may present a higher mailing cost to institutions, the inclusive information is important to prospective applicants. For example, although the program bulletin may describe comprehensively the psychology program of interest, information on housing, cost of living, and community life may only be available in the broader university catalogue. Tangential information (e.g., catalogues from other departments) need not be included in the mailing.

2. Generally, the physical quality of the packets should be reviewed and improved. Many of the department and program forms were poorly printed and xeroxed, and in some cases they were virtually illegible. The university catalogues were of much better quality. In the Yoshida et al. (1989) study, some of the packets arrived ripped and tattered. The material should be carefully packaged and mailed.

3. The application and admission process should be clearly delineated. For example, the reader should be able to assess quickly which forms need to be completed by what date, how the admission's process works (e.g., are personal or group interviews part of the process), and what the time line is for final notification. A couple of participants wished that programs had a toll-free telephone number to call to ask specific questions. Programs may want to consider implementing this recommendation in some form.

4. The admissions criteria should be clearly delineated. For example, are minimum GRE scores used in screening out applicants? How many applicants apply and are admitted each year? Is applied experience on the bachelor's-degree or master's-degree level valued?

Professional Psychology: Research and Practice, Vol. 26, No. 2 (April 1995): pg. 196-204. DOI. This article is @ American Psychological Association and permission has been granted for this version to appear in e-Publications@Marquette. American Psychological Association does not grant permission for this article to be further copied/distributed or hosted elsewhere without the express permission from American Psychological Association. 
NOT THE PUBLISHED VERSION; this is the author's final, peer-reviewed manuscript. The published version may be accessed by following the link in the citation at the bottom of the page.

5. Financial aid information should be specifically and candidly discussed. For example, what percentage of incoming students receive aid each year? Is the aid usually in the form of teaching assistantships, research assistantships, or graduate assistantships? Do assistantships or scholarships carry beyond the first year? Is there professionally relevant part-time work available off-campus?

Application packets could include a resource guide to helping student applicants find sources of funding. The guide could list resources for obtaining grants, scholarships (e.g., APA minority fellowship), loans, aid, and so on specifically geared toward members of racial-ethnic minority groups.

Application packets should also include information on the cost of living in the community. For example, $\$ 10,000$ in aid at the University of Iowa will go much further than the same amount of aid at New York University. The availability of and average cost of housing, car insurance, electricity, and so on should be specified.

6. Participants in our study were very interested in gathering a comprehensive picture of their specific program of interest. Packets should include a program handbook of some form that describes the program at length: the philosophy of the program; the theoretical orientation and research interests of the core-program faculty; the sequencing of courses, research experiences, and practicum; complete course descriptions; and the internship and dissertation process.

7. The handbook could also give demographic information on the student body, faculty (program and university-wide), and recent program graduates. An employment profile of recent graduates would also be valued by prospective applicants.

8. Programs should consider developing a community resource guide specifically geared to serving minority students. The guide could include sources for groceries, churches, community centers, hairdressers, professional associations, cultural centers, restaurants, day-care centers, performing arts, and so on. Pictures of students interacting in the community would also be particularly valued by prospective applicants. Many of our participants based in New York were hesitant to leave their city unless they could gather a complete

Professional Psychology: Research and Practice, Vol. 26, No. 2 (April 1995): pg. 196-204. DOI. This article is @ American Psychological Association and permission has been granted for this version to appear in e-Publications@Marquette. American Psychological Association does not grant permission for this article to be further copied/distributed or hosted elsewhere without the express permission from American Psychological Association. 
and accurate picture of community life in the university town under consideration.

9. A program's multicultural interest and commitment should be reflected in the handbook and catalogues. For example, programsponsored minority-affairs committees, multicultural-multilingual research teams and related student-faculty research, multiculturally oriented field experiences, and so forth could be highlighted in the materials. The reader will recall that the Bernal et al. (1983) study found a modest correlation between minority-specific information included in application packets and the number of minority students enrolled in the program.

10. Participants in our sample appreciated the packets that included a personally addressed cover letter. Given that many minority students perceive doctoral training as hostile to persons of color (Ponterotto, Lewis, \& Bullington, 1990), creating a bridge to the university and program through an identified contact person would be helpful. Listing the volunteer names and telephone numbers of matriculated program students or recent graduates for the prospective applicant to call would be attractive to prospective students. Furthermore, if the program has a "student buddy" system that pairs current students with new admits of a similar background to assist them with program and city adjustment, then this can be specified in the program handbook.

\section{Limitations and Directions for Future Research}

Limitations of the present study reflect the methodology incorporated. Our qualitative procedures allowed us to gather an indepth understanding of how a select group of potential doctoral students in professional psychology process and evaluate programs vis-à-vis their application packets. Although we are confident in the accuracy of our result interpretation given the triangulation methods used, it is clear that our results are not readily generalizable.

This study focused on the experiences of Black and HispanicAmerican students only, as these groups are a prime focus of the profession's current and projected recruitment emphasis (Ponterotto \& Casas, 1991). It is likely, however, that some of our findings would 
also reflect the views and perceptions of prospective applicants from the "majority" group (White Americans). Future research may want to examine differential perceptions of majority and minority students toward the doctoral application and admissions process. Other comparisons could be made within select groups, for example, on the basis of whether the applicant is a "first-generation" professional student, socioeconomic status differences, geographic variations, or differences based on acculturation or racial-ethnic identity development levels.

The themes identified in this study could be further explored through more focused qualitative methods. For example, future methodologies might involve fully unstructured interviews with only a few participants or intensive case studies of one or two students in the midst of the application process. The results of the present theme analysis can also form the foundation for quantitative research. Future researchers can develop an objective survey questionnaire on the basis of the major and minor themes identified and then sample large numbers of geographically dispersed prospective doctoral applicants.

This exploratory study was designed to provide some insight into the perceptions of minority students who could be said to be in the application pool for doctoral programs in counseling and school psychology. We hope this study has highlighted the relevance of qualitative methods to the topic and will stimulate additional empirical research in the area.

\section{Notes}

- JOSEPH G. PONTEROTTO received his PhD in counseling psychology in 1985 from the University of California at Santa Barbara. Currently, he is Professor of Education in the counseling programs at Fordham University at Lincoln Center.

- ALAN BURKARD is a doctoral candidate in counseling psychology at Ford-ham University. At present he is completing his predoctoral internship at the Counseling Center, Northern Illinois University.

- ROLAND K. YOSHIDA received his PhD from the University of Southern California in 1974. He is now Dean of the School of Education, and Professor of Special Education at Queens College, City University of New York.

- ANTHONY A. CANCELLI received his EdD from Oklahoma State University in 1976. He is currently a Professor and coordinator of the

Professional Psychology: Research and Practice, Vol. 26, No. 2 (April 1995): pg. 196-204. DOI. This article is @ American Psychological Association and permission has been granted for this version to appear in e-Publications@Marquette. American Psychological Association does not grant permission for this article to be further copied/distributed or hosted elsewhere without the express permission from American Psychological Association. 
school psychology program at Fordham University. He also served as Associate Dean and Director of Graduate Studies for the School of Education.

- GIOVANNI MENDEZ is a doctoral candidate in the school psychology program at Fordham University. He received his professional diploma in school psychology in 1991 and practices as a school psychologist in the Huntington Union Free School District, New York.

- LYNN WASILEWSKI is a doctoral candidate in educational psychology at Fordham University.

- LYNN SUSSMAN is a doctoral candidate in counseling psychology at Fordham University.

- A more expanded version of this article was presented at the $102 \mathrm{nd}$ Annual Convention of the American Psychological Association, 1994, Los Angeles.

- Correspondence concerning this article should be addressed to Joseph G. Ponterotto, Division of Psychological and Educational Services, Room 1008, Fordham University at Lincoln Center, 113 West 60th Street, New York, New York 10023-7478.

- $\quad{ }^{1}$ Copies of the coding sheets and general interview guide are available from Joseph G. Ponterotto.

- ${ }^{2}$ Graduate Record Examination and GRE are registered trademarks of Educational Testing Service

\section{References}

Aanstoos, C. M. (1983). The think aloud method in descriptive research. Journal of Phenomenological Psychology, 14, 243-266.

American Psychological Association. (1990). Ethical principles of psychologists (amended June 2, 1989). American Psychologist, 45, 390-395.

Bernal, M. E., Barron, B. M., \& Leary, C. (1983). Use of application materials for recruitment of ethnic minority students in psychology. Professional Psychology: Research and Practice, 14, 817-829.

Casas, J. M., \& Thompson, C. E. (1991). Ethical principles and standards: A racial/ethnic minority research perspective. Counseling and Values, 35, 186-195.

Graduate Record Examination. (1994). Princeton, New Jersey: Educational Testing Service.

Professional Psychology: Research and Practice, Vol. 26, No. 2 (April 1995): pg. 196-204. DOI. This article is @ American Psychological Association and permission has been granted for this version to appear in e-Publications@Marquette. American Psychological Association does not grant permission for this article to be further copied/distributed or hosted elsewhere without the express permission from American Psychological Association. 
NOT THE PUBLISHED VERSION; this is the author's final, peer-reviewed manuscript. The published version may be accessed by following the link in the citation at the bottom of the page.

Hammond, W. R., \& Yung, B. (1993). Minority student recruitment and retention practices among schools of professional psychology: A national survey and analysis. Professional Psychology: Research and Practice, 24, 3-12.

Helms, J. E. (1989). At long last-paradigms for cultural psychology research. The Counseling Psychologist, 17, 98-101.

Hills, H. I., \& Strozier, A. L. (1992). Multicultural training in APA-approved counseling psychology programs: A survey. Professional Psychology: Research and Practice, 23, 43-51.

Kerwin, C., Ponterotto, J. G., Jackson, B. L., \& Harris, A. (1993). Racial identity in biracial children: A qualitative investigation. Journal of Counseling Psychology, 40, 221-231.

Marshall, C., \& Rossman, G. B. (1989). Designing qualitative research. Newbury Park, CA: Sage.

McCracken, G. (1988). The long interview (Sage University Paper Series on Qualitative Research Methods, Vol. 13). Newbury Park, CA: Sage.

Meyers, J., \& Lytle, S. (1986). Assessment of the learning process. Exceptional Children, 53, 138-144.

Ponterotto, J. G., \& Casas, J. M. (1991). Handbook of racial/ethnic minority counseling research. Springfield, IL: Charles C Thomas.

Ponterotto, J. G., Lewis, D., \& Bullington, R. (1990). Affirmative action on campus. San Francisco: Jossey-Bass.

Rogers, M. R., Ponterotto, J. G., Conoley, J. C., \& Wiese, M. J. (1992). Multicultural training in school psychology: A national survey. School Psychology Review, 21, 603-616.

Schofield, J. W., \& Anderson, K. (1987). Combining quantitative and qualitative components of research on ethnic identity and intergroup relations. In J. S.Phinney \& M. J.Rotheram (Eds.), Children's ethnic socialization: Pluralism and development (pp. 252-273). Newbury Park, CA: Sage.

Professional Psychology: Research and Practice, Vol. 26, No. 2 (April 1995): pg. 196-204. DOI. This article is @ American Psychological Association and permission has been granted for this version to appear in e-Publications@Marquette. American Psychological Association does not grant permission for this article to be further copied/distributed or hosted elsewhere without the express permission from American Psychological Association. 
NOT THE PUBLISHED VERSION; this is the author's final, peer-reviewed manuscript. The published version may be accessed by following the link in the citation at the bottom of the page.

Stage, F. K., \& Russell, R. V. (1992). Using method triangulation in college student research. Journal of College Student Development, 33, 485491.

Sue, D. W., Carter, R. T., Casas, J. M., Fouad, N. A., Helms, J. E., Ivey, A. E., LaFromboise, T., Manese, J. E., Ponterotto, J. G., \& Vasquez-Nuttal, E. (1992, August). Cross-cultural counseling competencies:

Revised.Symposium presented at the 100th Annual Convention of the American Psychological Association, Washington, DC.

Sue, D. W., \& Sue, D. (1990). Counseling the culturally different: Theory and practice (2nd ed.). New York: Wiley.

Taylor, S. J., \& Bogdan, R. (1984). Introduction to qualitative research methods: The search for meanings. New York: Wiley.

Weinstein, C., \& Mayer, R. E. (1986). The teaching of learning strategies. In M. C.Wittrock (Ed.), Handbook of research on teaching (3rd ed.(pp. 315-327). New York: Macmillan.

Yoshida, R. K., Cancelli, A. A., Sowinski, J., \& Bernhardt, R. (1989). Differences in information sent to minority and nonminority prospective applicants to clinical, counseling, and school psychology programs. Professional Psychology: Research and Practice, 20, 179184.

Professional Psychology: Research and Practice, Vol. 26, No. 2 (April 1995): pg. 196-204. DOI. This article is @ American Psychological Association and permission has been granted for this version to appear in e-Publications@Marquette. American Psychological Association does not grant permission for this article to be further copied/distributed or hosted elsewhere without the express permission from American Psychological Association. 
NOT THE PUBLISHED VERSION; this is the author's final, peer-reviewed manuscript. The published version may be accessed by following the link in the citation at the bottom of the page.

\section{Appendix}

\section{Table 1: Characteristics of the Four Application Packets for Programs in Professional Psychology}

\begin{tabular}{|c|c|c|c|c|}
\hline \multirow[b]{3}{*}{ Variable } & \multicolumn{4}{|c|}{ University } \\
\hline & \multicolumn{2}{|c|}{ Counseline psychology } & \multicolumn{2}{|c|}{ School psychology } \\
\hline & $\begin{array}{l}\text { New York } \\
\text { University }\end{array}$ & $\begin{array}{l}\text { Kent State } \\
\text { University }\end{array}$ & $\begin{array}{l}\text { University of } \\
\text { South Forida }\end{array}$ & $\begin{array}{c}\text { University } \\
\text { of lowa }\end{array}$ \\
\hline \multicolumn{5}{|c|}{ General applicant information } \\
\hline APA accreditation status & $\mathrm{Y}^{*}$ & $\mathbf{Y}^{*}$ & $\mathbf{N}$ & $\mathbf{Y}^{*}$ \\
\hline \multicolumn{5}{|l|}{ Introduction letter to students } \\
\hline Personal letter & $\mathbf{N}$ & $\mathbf{Y}$ & $\mathrm{N}$ & $Y$ \\
\hline Form letter & $\mathbf{Y}$ & $\mathbf{N}$ & $\mathbf{Y}$ & $\mathbf{N}$ \\
\hline Handwritten noce & $\mathrm{N}$ & $\mathbf{N}$ & $\mathrm{N}$ & $\mathrm{N}$ \\
\hline Specific contact person & N & $\mathbf{Y}$ & $\mathbf{Y}$ & $\mathrm{Y}$ \\
\hline Program brochure & $\mathbf{Y}$ & $\mathbf{N}$ & $\mathbf{Y}$ & $\mathbf{Y}$ \\
\hline Application form & $\hat{\mathbf{Y}}$ & $\mathrm{N}$ & $\mathbf{Y}$ & $\dot{Y}$ \\
\hline Outline of appikeation procedures & $\mathbf{Y}$ & $\mathrm{Y}$ & $\mathbf{Y}$ & $\mathbf{Y}$ \\
\hline Financial aid information & $\mathbf{Y}$ & $\mathbf{Y}$ & $\mathbf{Y}$ & $\mathbf{Y}$ \\
\hline Financial aid forms & $\mathbf{Y}$ & $\mathbf{N}$ & $\mathbf{N}$ & $\mathrm{N}$ \\
\hline Recommendation forms & $\dot{Y}$ & $\mathrm{NA}^{*}$ & $N A^{*}$ & $\mathbf{Y}$ \\
\hline GRE scores required & $\mathbf{Y}$ & $\mathbf{Y}$ & $\mathbf{Y}$ & $\mathbf{Y}$ \\
\hline GRE Psychology subest required & $\mathbf{N}$ & $\mathbf{N}$ & $\mathrm{N}$ & $\mathrm{N}$ \\
\hline Faculty rescarch interests & $\mathbf{Y}$ & $\mathbf{Y}$ & $\gamma$ & $\mathrm{N}$ \\
\hline Curriculum outline/program & $\mathbf{Y}$ & $\mathbf{Y}$ & $\mathrm{N}$ & $\mathbf{Y}$ \\
\hline Commsnity/city information & $\mathrm{N}$ & $\mathrm{N}$ & $\mathrm{N}$ & $\mathrm{Y}$ \\
\hline \multicolumn{5}{|c|}{ Minority reeruitment information } \\
\hline \multicolumn{5}{|l|}{ Minority training opportunities } \\
\hline Research & $\mathrm{N}$ & $\mathrm{N}$ & $\mathrm{N}$ & $\mathrm{N}$ \\
\hline Practicum & $\mathrm{N}$ & $\mathrm{N}$ & $\mathrm{N}$ & $\mathbf{N}$ \\
\hline University aid specific to minorities & $\mathrm{Y}$ & $N^{k}$ & $\mathrm{~N}^{n}$ & $\mathrm{Y}^{\mathrm{e}}$ \\
\hline \multicolumn{5}{|l|}{ Information on outside } \\
\hline Financial aid resources for minorities (e \&., APA) & $\mathbf{N}$ & $\mathbf{N}$ & $\mathrm{N}$ & $\mathbf{Y}$ \\
\hline Special admissions criteria for minorities & $\mathrm{N}$ & $\mathrm{N}$ & $\mathrm{N}$ & $\mathrm{N}$ \\
\hline Demographics of student body (e.s. ethnicity, Bender) & $\mathrm{N}$ & $\mathbf{Y}$ & $\vec{N}$ & $\mathrm{~N}$ \\
\hline Minority faculty mentionod & $\mathrm{N}$ & $\mathrm{N}$ & $\mathrm{N}$ & $\mathbf{N}$ \\
\hline Courses oriented to multicultural issues & $\dddot{Y}$ & $\dddot{Y}$ & $\mathrm{~N}$ & $\mathrm{~N}$ \\
\hline
\end{tabular}

Note. $\mathrm{Y}=$ Information was included in the recruitment and application packets; $\mathrm{N}=$ Information was not included in the recruitment and application packets; APA = American Psychological Association; GRE = Graduate Record Examination. a Current status is full APA accreditation. b Not applicable; programs require independent letters. c Note that most graduate students receive graduate assistantships 